\title{
AN EFFICIENT COUNTY COURT SYSTEM
}

\author{
By Herbert harley, \\ Secretary, American Judicature Society, Chicago, Ill.
}

Our judicial system hardly makes a pretense of affording good service to the greatest number of litigants. The courts frequented by persons whose claims involve small amounts are seldom considered in respect to reform of judicial procedure. Lawyers are little concerned with the conduct of inferior courts. No considerable part of their income is derived from this source. Practice in them is limited to young lawyers eager for experience but willing to give up this "chicken-feed" business as soon as their situation permits.

This is a principal reason why these popular tribunals escape serious criticism. It is easier to make a joke of them. The few serious opinions voiced are profoundly skeptical. Here and there are found capable magistrates and judges and the belief prevails that inferior courts can never be better except as they chance from time to time to obtain the services of judges who combine knowledge of the law with energy, courage and tact. Such instances are purely fortuitous. A common idea of representative institutions is that they can be expected to do no more than represent the meanest ideals of the community.

Here seems to be the real trouble: that we have not thought of shaping a system that would attract to this arduous service exceptional qualities, the best that the community possesses. We most lack an ideal of what a local court of limited jurisdiction may become, notwithstanding the fact that certain other countries have solved the problem. It is true that we have a healthy movement looking to the reformation or effacement of the petty tribunal in the large city, where it has been corrupt as well as incapable, but in rural districts the problems of inferior jurisdiction will persist.

More than half of the people of the United States live in counties that are classified as rural or semi-rural. In number of causes and in number of litigants these lesser courts will always exceed the more formal and dignified courts of full trial jurisdiction. Failure in this field of judicial administration is a disgrace as well 189 
as an economic burden. Our civilization is weak and pretentious until it finds a way to dispense real justice for the largest class of suitors in the country. Success cannot be left to depend upon remote contingencies. The county is the natural political unit for the structure of local courts. There are few counties so sparsely settled as to afford insufficient scope for a real judge. Such counties can be linked to others for administrative purposes. And there are comparatively few with populations large enough to make this an urban problem.

Our present inferior court systems exemplify our powerful inclination toward decentralization. They are courts of and for the people living in town and country. This is an inevitable and not unreasonable condition. The fact that they are democratic is no valid excuse for inefficiency. It is an unfriendly idea of democracy which excludes efficient service. Democracy, like every other ideal, must justify itself by its works.

In nearly every state the lowest of our judicial hierarchy is the justice of the peace. Among people of high capacity for selfgovernment this office has degenerated until it possesses no dignity and no reward. The occasional capable justice cannot offset the prevalent Dogberry type and his dependence upon fees tends powerfully to undermine his integrity. Having little or no supervision the office is deprived of the expert guidance which might improve its quality. There is as much good material in the average community for public service of this kind as ever; but we have created an environment which effectually excludes wisdom, talent and pride of service.

In many of the states there is also a County Court presided over by a lawyer-judge and serving the people of the largest town fairly well in respect to small causes. Where there is no County Court it is customary to establish in the larger towns special courts so that tolerable service is afforded residents of these favored localities.

Here exists the material for the construction of an ideal machine for administering justice in the average county. Let there first be one County Court having jurisdiction to a certain extent throughout the county. In most counties one county court judge would suffice. This one county judge should have such powers as would permit of holding him responsible for the administration of justice up to the limit of jurisdiction conferred upon his court. 
In counties not exceeding forty thousand population one judge could take care of all civil causes involving not more than $\$ 500$ and all criminal causes of the grade of misdemeanor. If he is given also all non-contested probate matters the establishment of the proposed system would nowhere add a cent to public expenditures and in many counties would effect a considerable saving.

The county judge should be empowered to hold court anywhere in his county, taking justice to remote parts, rather than requiring numerous parties and witnesses to travel a considerable distance. His court should always be open at the county seat, or most populous town in the county, but there should be regular days, weekly or monthly, for holding court in lesser centers.

This simple and flexible system will provide for nearly all of the civil causes. But it will be found desirable to have branches of the County Court, or deputies of the county court judge, at convenient points in the rural districts for speedy action when criminal process is applied for. The justice of the peace, properly adapted to this function, may well serve as deputy judge. The fact that he is a layman will be no objection because he will be guided by his responsible superior. An authorized stipend should take the place of random fees.

To avoid confusion let us call this reformed justice a district magistrate. There is no need for providing such an officer for every township or supervisor district. The number of magistrates should be adapted to needs. A number from six to ten would be enough for most counties. The county should be districted to give a proper area and population to each. In most cases the district could include a village conveniently reached by every inhabitant of the district.

The method of selecting these magistrates is of first importance. They should be county officials and, since they are to serve with the county judge and under his supervision, he should have a voice in their selection. At the same time it may be well to protect the judge from undue solicitation. A happy compromise seems to be reached in the proposal that the magistrates should be appointed by the county board with the consent of the county judge. Tenure should be for good behavior or until the county board and county judge concur in retiring them. Compensation should be in accordance with the volume of business done. Very good services could 
be obtained in many places for $\$ 100$ a year and probably $\$ 500$ would suffice for those most frequently called upon.

The jurisdiction of the magistrates should be most elastic. The idea is to encourage the use of these local Solomons as long as they please their constituents and to permit of passing over their heads whenever distrust is evidenced. They might well be empowered to decide any civil suit within the county court jurisdiction when all parties wish them to do so. They should be permitted to function in all matters expressly assigned to them by their superior. Finally the county judge should have power to remove any matter from them for his own consideration at any time before judgment is rendered, and to grant a new trial at his discretion.

As to issuing warrants it is presumed that they would act under instructions of the county judge whenever his council is available and according to rules laid down by him at other times. They should have power to try in cases of misdemeanor with the consent of the accused and of the county judge.

It is presumed that magistrates will not impanel juries. The farce of the jury trial presided over by the lay judge must be abolished. Under a responsible system there would be fewer jury trials, and such as are demanded should be conducted by the county judge at one of the regularly appointed places for holding county court trials. A jury of six is large enough for such a jurisdiction, and if the judge is not permitted to express his opinion of the evidence, a verdict should be permitted by five jurors.

Now we have projected a simple, economical responsible local court system adaptable to the great majority" of counties. It utilizes existing agencies with a minimum of departure from current practice. It is easy to picture its operation in the typical county where there are telephones and reasonably good facilities for travel. Every inhabitant of such a county would have an arm of the court within an hour's travel from his doorstep. The entire system would be managed by one responsible judge, easily the most important and dignified official in the county. Every litigant would have his choice between his home magistrate and the county judge and this arrangement alone would go far to obviate the heartburning, the vindictiveness and the feud-quality of local litigation. Litigation would be economical and at the same time would possess that quality of satisfaction and finality which is to be sought above 
all else. There would be few appeals and these could be heard by the circuit judge on a record made up by the County Court, obviating our present foolish but necessary plan of trying all such appeal cases de novo.

In counties having more than forty thousand population there could be an associate county judge, answerable in a ministerial way to the senior county judge. In counties not too populous these two judges could fill the field so well as to leave room for only a few lay assistants. Specialization could raise the efficiency of each of these judges to one hundred per cent. One could sit most of the time at the largest town while the other went about the county on circuit, or they could specialize on civil and criminal calendars. The need for special economy in certain causes, expressed by the creation of the Small Debtors' Courts in Kansas and Oregon, would be met without any special machinery. The system would be flexible enough to keep abreast of social demands without special enactment. One clerk would suffice for the entire county system and he should be the clerk of the Circuit Court. Each district magistrate would be a deputy clerk for his district. A deputy sheriff in each district, paid by fees, and a special deputy sheriff to accompany the county judge on circuit, would obviate the need for local constables and insure responsibility in the executive arm of the court.

This essentially local and democratic system can retain popular selection with prospects of high success. The county is a wieldy district from the short ballot standpoint. All the voters of a county are fairly well informed of the reputation and general qualifications of the local bar. The office of judge would be a conspicuous one. A non-partisan ballot for nomination and election would work well in so small a constituency. The term should be for a reasonable period of years. If any improvement is sought in methods of election it should be by permitting the judge, at the end of his term, to "run on his record." Under this plan the voters would vote yes or no on the question of reelecting him. This would insure reëlection unless there were substantial reasons for retiring the judge, and this is as it should be. Judges must be independent and this implies freedom from undue menace. The common method of electing judges injects into the mind of the judge in numerous causes that very personal interest which is most rightly condemned 
as incidental to the judicial recall. The public must give judges reasonable assurance of continued service if it is to compete successfully with the rewards of private practice. Security of tenure has the practical advantage also of making up in part for moderate salaries.

Without departing from our tradition of local government it is possible to develop certain proposals which would strengthen our model County Court. With such courts in all or nearly all the counties of a state they should be considered as forming together a county court division of the state judicial system. The county court judges should have a state organization and should meet once in every year to compare methods of administration. They should make full judicial and administrative reports monthly to a supervising judge of County Courts whose duty it would be to digest and publish these statistics, to counsel with county judges regarding their unusual problems, to provide for uniformity in administration and reporting, and to suggest means for simplifying procedure and economizing effort. It might well be the duty of the supervising judge to visit all counties periodically.

If there were in such a state a thorough coördination of all judges, such as is implied in the newer ideal of a unified state court system, the county court division could be even more usefully coördinated. The county judge could be a local master for the Circuit Court. He could also officiate in the trial of felony cases by direction of the circuit judge and so reduce the number of days of jail confinement for prisoners awaiting trial.

It may be said finally that any such system implies large powers for self-regulation. This means that the county courts should not be tied down to a minutely legislated code of procedure. The statutes should determine the larger elements of procedure and confer power upon the county judges in annual assembly to amend the schedule of court rules. In administrative matters each judge should have a free hand subject to supervision by any judicial council of the state charged with this general responsibility. A judge not to be trusted to use common sense in the ordinary business of his court cannot be trusted to give good results under the most rigid and minute of legislated codes. Supervision and responsible personal direction should take the place of statutory control. No amount of statutory law can make an efficient official out of in- 
different material but it can easily defeat good results from capable officials. In the judicial field minute and rigid procedure only serves to multiply litigation and make it a matter of form rather than of substance.

The real check upon abuse of power and failures of omission must come from enlightened public opinion. The field of the local judiciary is ideally subject to the discipline of public opinion when adequate power and freedom exist. It has the further discipline afforded by the bar and that arising from the right of the disappointed litigant to have a higher court pass upon his cause. ${ }^{1}$

${ }^{1}$ Readers are referred to Bulletin VII-A, American Judicature Society, for a draft of an act to establish a county court system as projected above, and to make it a coördinate part of a unified state court system. The only state in which a serious effort has been made to improve inferior courts in rural districts is New Hampshire. See Laws of 1913, chapter 169. 